\title{
„CZUWAĆ JAK NAJTROSKLIWSZA MATKA NAD DZIECKIEM". DZIALANIA MATKI KAZIMIERY GRUSZCZYŃSKIEJ W KIERUNKU PRZYGOTOWANIA SIÓSTR FRANCISZKANEK OD CIERPIĄCYCH DO PRACY PIELĘGNIARSKIEJ
}

Założone w 1882 roku w Warszawie Zgromadzenie Sióstr Franciszkanek od Cierpiących ${ }^{1}$ od początku swego istnienia opiekę nad chorymi i potrzebującymi traktowało jako swoje najważniejsze powołanie i obowiązek. Zgromadzenie, ustanowione jako jedno ze zgromadzeń ukrytych powstałych z inicjatywy bł. o. Honorata Koźmińskiego, zajmować się miało niesieniem pomocy i opieką nad ludźmi cierpiącymi $^{2}$. Rozwinęło więc bardzo szeroką działalność nie tylko na polu opieki nad chorymi w domach prywatnych czy szpitalach, ale również działalność dobroczynną prowadzoną w licznych placówkach i obejmującą swym zasięgiem wiele obszarów aktywności.

Postawione przed Zgromadzeniem zadania napotykały na niemało przeszkód tak natury finansowej jak i organizacyjnej. Nie ułatwiał pracy fakt, że założycielka i pierwsza przełożona Zgromadzenia, Kazimiera Gruszczyńska, aż do końca 1908 roku formalnie była członkinią innego zgromadzenia honorackiego - Posłanniczek Serca Jezusowego.

\footnotetext{
${ }^{1}$ Początkowo Zgromadzenie nosiło nazwę „Siostry Cierpiących”, dopiero w 1909 r. zmieniono ją na „Siostry Franciszkanki od Cierpiących”.

2 Informacje historyczne na temat działalności Zgromadzenia Sióstr Franciszkanek od Cierpiących podaję na podstawie prac: L. C zermińska, Wszystko zaczęło się w Kozienicach. Życie i dzieło Stugi Bożej Kazimiery Gruszczyńskiej (1848-1927), Kozienice 2017; K. D ę b o w s k a, Zgromadzenie Sióstr Franciszkanek od Cierpiących w latach 1882-1952, „Prawo Kanoniczne. Kwartalnik Prawno-Historyczny”, t. 15, 1972, nr 1-2, s. 159-229; D. O 1 s z e w s k i, W stużbie cierpiacym. Charyzmat Kazimiery Gruszczyńskiej (1848-1927), Niepokalanów 1991; J. S t ę p i e ń, Rys życia Kazimiery Gruszczyńskiej, [w]: Polskie teksty ascetyczne, red. J. B a r, t. II, Warszawa 1981, s. 227-282.
}

„Nasza Przeszłość” t. 131: 2019, s. 103-131. 
Jednak mimo to, a może na przekór wielu trudnościom, Siostry Franciszkanki od Cierpiących rozwinęły trudną do przecenienia działalność w zakresie opieki nad chorymi i potrzebującymi. Szczególnie poprzez trud pielęgnowania chorych wypełniły ogromną lukę, jaka istniała wówczas w Królestwie Polskim i na pozostałych ziemiach polskich pod zaborem rosyjskim.

Wiek XIX przyniósł w stosunku do okresu wcześniejszego zmianę w sposobie funkcjonowania szpitali. Stopniowo przestawały one być przytułkami dla starców, bezdomnych, sierot czy samotnych kobiet ciężarnych, niosącymi jedynie podstawową pomoc medyczną, a zaczęły przekształcać się w instytucje przeznaczone wyłącznie dla chorych wymagających leczenia. Był to proces następujący powszechnie, jednak ze względu na terytorialne ramy działalności Zgromadzenia, głównie ograniczające się do ziem Królestwa Polskiego ${ }^{3}$, omówiona zostanie pokrótce jedynie sytuacja szpitalnictwa na tym terenie ${ }^{4}$.

Istotne zmiany w organizacji opieki medycznej nastąpiły już w początkach istnienia Królestwa Polskiego. W 1817 roku chcąc ujednolicić obowiązki i sposób funkcjonowania szpitali powołano Radę Główną Dozorczą, której zadaniem było sprawowanie ogólnej opieki i nadzoru nad nimi, oraz Rady Szczegółowe Dozorcze przy poszczególnych szpitalach. Taka mocno zbiurokratyzowana struktura wprowadzała wprawdzie jednolite reguły w zarządzaniu placówkami, lecz nie przyczyniła się do ich sprawnego funkcjonowania.

$\mathrm{Z}$ tego powodu w 1832 roku ustanowiono - analogicznie - Radę Główną Opiekuńczą oraz podległe jej Rady Szczegółowe Opiekuńcze, sprawujące nadzór nad istniejącymi szpitalami i zakładami dobroczynnymi, a także zajmujące się tworzeniem nowych. Rada Głowna ułożyła instrukcję dla Rad Szczegółowych, w której znalazły się zapisy określające wewnętrzną organizację szpitali, w tym także podstawowe zasady opieki nad chorymi.

Zamknięcie po powstaniu listopadowym Uniwersytetu Warszawskiego spowodowało duże zainteresowanie lekarzy, dotąd zatrudnionych w klinikach, praktyką szpitalną. Kształcący się od tej pory za granicą lekarze starali się wykorzystywać w swojej praktyce najnowsze

\footnotetext{
${ }^{3}$ Siostry prowadziły także działalność na ziemiach polskich włączonych do Cesarstwa Rosyjskiego oraz w Poznaniu (w l. 1888-1894) i Krakowie (w l. 1893-1894).

${ }^{4}$ Zob. E. M a zu r, Szpitale w Królestwie Polskim w XIX wieku, Warszawa 2008; a także Z. P o d g ó r s k a - K l a w e, Szpitale warszawskie 1388-1945, Warszawa 1975.
} 
osiągnięcia medycyny europejskiej. Także działalność Towarzystwa Lekarskiego i wydawane publikacje fachowe miały wpływ na poprawę jakości leczenia w szpitalach.

W 1842 roku wydano przepisy o organizacji i zarządzaniu szpitalami, które szczegółowo odnosiły się do wszystkich aspektów ich działalności, poddawały także zarządzanie szpitali kontroli państwowej. Rada Główna Opiekuńcza zyskała większą samodzielność. Wprowadzono jednolite dla wszystkich placówek szczegółowe zapisy dotyczące wewnętrznej organizacji szpitali, jasno formułując zasadę, że są one przeznaczone jedynie dla chorych. Wpłynęło to na podniesienie poziomu leczenia, dając równocześnie lekarzom możliwość dostosowania organizacji szpitali do wymogów najnowszych osiągnięć medycyny. Wadą nowych uregulowań było jednak oparcie finansów zakładów leczniczych głównie na ofiarności obywateli, funduszach własnych szpitali i na dotacjach państwowych, a także wciąż zbyt mała reprezentacja lekarzy w Radzie Głównej Opiekuńczej.

Wśród niezrealizowanych planów, jakie postawiła przed sobą Rada Główna Opiekuńcza było wprowadzenie tak zwanych garde malades, osób zajmujących się posługą chorym, czyli pielęgniarek i pielęgniarzy. Prawdopodobnie brak funduszy spowodował, że tak nagląca potrzeba nie została zrealizowana.

Rady Opiekuńcze funkcjonowały do 1870 roku i przyczyniły się do znacznego rozwoju szpitalnictwa na terenie Królestwa Polskiego. Licznie powstawały nowe i remontowano już istniejące szpitale, planowano powoływanie placówek specjalistycznych (otwartych ostatecznie po 1870 roku). Zrodziły się wówczas podstawy medycyny szpitalnej, zakładającej między innymi stałą opiekę lekarską.

Ukazem z 1870 roku zlikwidowano Radę Główną Opiekuńczą i Rady Szczegółowe oddając szpitale w Królestwie Polskim pod władzę Ministerstwa Spraw Wewnętrznych w Petersburgu. Likwidację rad należy przyjmować, jako jedną z represji władz rosyjskich po upadku powstania styczniowego. W jej wyniku nastąpiło całkowite podporządkowanie szpitali władzom państwowym, poprzez oddanie ich pod zarząd nowo powstałych gubernialnych i powiatowych Rad Dobroczynności Publicznej oraz Rady Miejskiej Dobroczynności Publicznej w Warszawie 5 . ${ }^{5}$ Po 1870 r. liczni lekarze podejmowali starania o poprawę sytuacji w szpitalach,
a przede wszystkim o dopuszczenie do udziału w ich zarządzaniu. Zabiegi te wpłynęły 
Zbiurokratyzowanie i upolitycznienie instytucji, którym powierzono zarząd szpitali wpłynęło zdecydowanie niekorzystnie na ich funkcjonowanie, szczególnie negatywny wpływ miało na działalność szpitali prowincjonalnych, gdzie lekarze odgrywali znacznie mniejszą rolę w zarządzaniu placówkami niż w Warszawie. Nowa organizacja administrowania szpitalami w konsekwencji doprowadziła nie tylko do chaosu w ich zarządzaniu, ale także do niestabilności finansowej, na co wpływ miało również znaczne ograniczenie dotacji przekazywanych przez obywateli, tracących zaufanie do nowego zarządu szpitali.

Zasady działania personelu medycznego określała Ustawa dla szpitali cywilnych w Królestwie Polskim z 1842 roku. Zakładała ona dostosowanie liczby lekarzy w szpitalach do wielkości szpitala, liczby pacjentów i rodzajów leczonych chorób. W szpitalach mniejszych miał być jeden lekarz (pełniący równocześnie funkcję lekarza naczelnego i ordynatora), w większych jeden lekarz miał przypadać na 100 pacjentów. Jeden $\mathrm{z}$ nich pełnił funkcję lekarza naczelnego, nadzorującego całość pracy szpitala. Każdy lekarz miał swój oddział, gdzie do pomocy dysponował felczerami (jednym na 50 pacjentów) oraz uczniami felczerskimi. Miał obowiązek opiekować się chorymi, wykonywać codzienne obchody, prowadzić karty historii chorób (zawierające informacje o leczeniu i przepisywanych lekach) oraz przybywać do szpitala na każde wezwanie. Zadaniem felczera była pomoc lekarzowi i opieka nad pacjentami. Brał udział w obchodzie i przyjmował wówczas polecenia lekarza co do opieki medycznej nad chorymi, nadzorował przyjmowanie przez nich leków i ich dietę, prowadził statystykę ruchu chorych, wykonywał sekcje zwłok pod nadzorem ordynatora.

Do personelu szpitalnego należeli jeszcze: intendent (zajmował się sprawami administracyjno-finansowymi, nadzorował pracę niższego personelu, kontrolował zachowanie pacjentów, składał radzie szpitala cotygodniowe sprawozdanie o ruchu chorych i opłatach przez nich wnoszonych), szafarz (opiekował się spiżarnią i magazynem oraz nad-

na wprowadzenie w 1894 r. w Królestwie Polskim ustawy, zgodnie z którą szpitalem miał zarządzać lekarz naczelny z pomocą dwóch innych lekarzy i intendenta, jednak bez możliwości swobodnego dysponowania finansami. Zmiany okazały się niestety pozorne. Dopiero w 1907 r. przeprowadzono ponowną reformę skutkującą tym razem poprawą systemu leczenia szpitalnego. Warszawskie szpitale (z wyjątkiem szpitali prywatnych i szpitala psychiatrycznego w Tworkach) oddano pod zarząd magistratu, w którym powołano Wydział Dobroczynności Publicznej. Zmiana ta miała znaczący wpływ na poprawę pracy szpitali, warunków w nich panujących oraz opieki nad chorymi. 
zorował kuchnię i piekarnię), dozorca salowy (sprawował nadzór nad poszczególnymi salami chorych, nadzorował też pracę posługaczy), posługacz (opiekował się chorymi, sprzątał sale, palił w piecach itp.).

W szpitalach pracowały także siostry ze Zgromadzenia Sióstr Miłosierdzia św. Wincentego a Paulo, stanowiąc stały personel podległy zarządom szpitali. Do ich obowiązków należało przede wszystkim podawanie leków, wykonywanie opatrunków, podawanie posiłków i ogólny nadzór nad chorymi. Siostry zajmowały się pielęgnowaniem chorych głównie w szpitalach warszawskich, w innych miejscowościach władze rosyjskie starały się zastępować szarytki zakonnicami prawosławnymi lub siostrami Rosyjskiego Czerwonego Krzyża, świadczącymi pacjentom znacznie gorszą opiekę. Próby odsuwania przez władze rosyjskie sióstr szarytek od pracy w szpitalach przez społeczeństwo polskie odczytywane były, jako element działalności rusyfikacyjnej. Budziło to sprzeciw i niejednokrotnie wpływało na wycofywanie zapisów na rzecz poszczególnych szpitali przez prywatnych darczyńców.

Sytuacja finansowa szpitali nie była łatwa, wpływ na to miało również niedostateczne finansowanie z kasy państwowej. Tymczasem wymogi rozwijającej się służby zdrowia powodowały konieczność zwiększania nakładów. Pewnym ratunkiem było, że oprócz dotacji państwowych szpitale korzystały także z państwowych zasiłków jednorazowych, dotacji prywatnych członków rodziny carskiej i dygnitarzy oraz z deputatów w naturze przyznawanych przez władze publiczne.

Rozwój nauk medycznych oraz stabilizacja szpitali, jako zakładów wyłącznie leczniczych, wpływały jednak na stopniowe budowanie zaufania pacjentów do leczenia szpitalnego. To z kolei powodowało wzrost liczby szpitali. I tak w 1903 roku na ziemiach zaboru rosyjskiego funkcjonowało 88 szpitali publicznych i 27 prywatnych $^{6}$. W tym czasie działają już także szpitale specjalistyczne oraz oddziały specjalistyczne w szpitalach.

Poważnym problemem był brak wykwalifikowanego personelu szpitalnego, do którego obowiązków należałoby pielęgnowanie chorych. Zajmowały się tym siostry szarytki, ale ich liczba była niewystarczająca (jedna siostra opiekowała się około 50 pacjentami) dodatkowo powierzano im obowiązki administracyjne. $Z$ kolei felczerzy byli tak nisko opłacani, że praktycznie czas ich pracy w szpitalach był mocno ograni-

${ }^{6}$ Zob. E. M a z u r, Szpitale w Królestwie Polskim, Aneks II i III, s. 147-151. 
czony, a jakość świadczonej opieki niewystarczająca. Zatem opiekę nad chorymi często przejmował niższy personel - dozorcy i posługacze. Źle opłacani i nieprzygotowani do tego rodzaju zajęcia.

W taką sytuację szpitalnej opieki medycznej w początku lat 80. XIX wieku wkracza Zgromadzenie Sióstr Franciszkanek od Cierpiących, i trudno przecenić rolę, jaką od tego momentu odegrało na polu pielęgnacji chorych.

Od samego początku funkcjonowania Zgromadzenia K. Gruszczyńska dostrzegała problem braku wśród sióstr wystarczającej liczby profesjonalnie przygotowanego personelu medycznego, równocześnie przykładała wielką wagę do właściwego zawodowego przygotowania sióstr, dlatego dbała, aby kształciły się w zakresie pielęgniarstwa już od momentu wstąpienia do zakonu. Angażowanie sióstr w opiekę nad chorymi w czasie postulatu miało też charakter formacyjny. Wykonywały wówczas najprostsze czynności, głównie higieniczne. W dalszej kolejności stopniowo przygotowywały się do współpracy z bardziej doświadczonymi siostrami i lekarzami ${ }^{7}$. W nowicjacie siostry franciszkanki były przygotowywane teoretycznie do pracy pielęgniarskiej, korzystały w tym celu przede wszystkim z dwóch podręczników: Rady dla osób oddajacych się pielęgnowaniu chorych ${ }^{8}$ (rękopiśmienny) oraz Zalecenia dla pielęgnujacych chorych $w$ zakładzie, $w$ szpitalach lub $w$ domach prywatnych ${ }^{9}$. Obok informacji odnoszących się ściśle do spraw medycznych, takich jak wiadomości na temat chorób i ich objawów, techniki wykonywania zabiegów, sporządzania leków, obserwacji chorego znajdują się tam także wzmianki z zakresu dietetyki i higieny. Oprócz tego informacje o cechach osobowych, jakie powinna mieć pielęgniarka, jak powinna się troszczyć o własne zdrowie, a także wskazówki dotyczące spraw natury duchowej, i to zarówno w stosunku do chorego jak i osoby, która się nim opiekuje. Miały nowicjuszki także ćwiczenia praktyczne ${ }^{10}$. Obowiązkowa lektura podręczników była

\footnotetext{
${ }^{7}$ Zob. K. D ę b o w s k a, Zgromadzenie, s. 222; J. S t ę p i e ń, Rys życia, s. 256.

${ }^{8}$ Archiwum Zgromadzenia Sióstr Franciszkanek od Cierpiących (dalej: AFC), sygn. A III, T. IV-Instr/53, 54, Rady dla osób oddających się pielęgnowaniu chorych, cz. 1 i 2.

${ }^{9}$ AFC, sygn. A III, T. III-Instr/33, Zalecenia dla pielęgnowania chorych w zakładach, szpitalach lub w domach prywatnych, s. 85-115.

${ }^{10}$ Zob. L. C ze r mińs k a, Wszystko zaczęto się, s. 87-88; K. D ę b o w s k a, Zgromadzenie, s. 221-222; D. O l s z e w s k i, W służbie cierpiacym, s. 97-98; J. S t ę p i e ń, Rys życia, s. 256.
} 
pierwszym krokiem na drodze kształcenia sióstr, ich przygotowania teoretycznego do wykonywania zadań pielęgniarskich.

Praktyki w pielęgniarstwie nabierały podczas pracy pod okiem lekarzy. Także siostry, które posiadały już pewne doświadczenie zawodowe miały zalecone uczyć zasad pielęgniarstwa młodsze, mniej doświadczone, a także osoby spoza Zgromadzenia ${ }^{11}$. Swoją wiedzę fachową od początku istnienia Zgromadzenia przekazywała siostra Magdalena Sasulicz ${ }^{12}$, która była felczerem, siostra Salomea Rajkow$\mathrm{ska}^{13}$, w 1907 roku wysłana na naukę do szkoły pielęgniarskiej w Hamburgu, a od 1918 roku także dr Konstancja Kulejewska ${ }^{14}$, absolwentka studiów medycznych w Genewie ${ }^{15}$.

Ponieważ do 1911 roku nie istniały na ziemiach polskich szkoły pielęgniarskie, K. Gruszczyńska sama podjęła trud zapewnienia siostrom możliwie najlepszego, jak na owe czasy, przygotowania do opieki nad chorymi. Ważnym elementem ich zawodowego przygotowania była praktyka, którą mogły odbywać w sposób nieskrępowany dzięki zaangażowaniu $\mathrm{w}$ pracę $\mathrm{w}$ szpitalach ${ }^{16}$. Zdawała sobie jednak sprawę, że kwestie fachowości powinny być ściśle zespolone z głęboką i świadomą religijnością. Dlatego ogromną wagę przywiązywała do zagwarantowania siostrom właściwej „formacji intelektualnej, duchowej i zawodowej”17.

${ }^{11}$ Zob. K. D ę b o w s k a, Zgromadzenie, s. 222.

12 S. Elżbieta, Magdalena Sasulicz (1850-1885), do nowicjatu przyjęta w 1881 r., pierwsze śluby złożyła w 1883 r. Z wykształcenia była felczerem, opiekowała się chorymi w Warszawie i Odessie, gdzie zaraziła się gruźlicą. Według wstępnych założeń, miała zastąpić K. Gruszczyńską na stanowisku przełożonej Zgromadzenia Sióstr Franciszkanek od Cierpiących.

${ }^{13}$ S. Małgorzata, Salomea Rajkowska (1868-1947), do nowicjatu przyjęta w 1894 r., pierwsze śluby złożyła w 1896 r., śluby wieczyste w 1910 r. W 1907 r. ukończyła szkołę pielęgniarską w Hamburgu.

${ }^{14}$ S. Alfonsa, Konstancja Kulejewska (1890-1982), do nowicjatu przyjęta w 1920 r., pierwsze śluby złożyła w 1922 r., a śluby wieczyste w 1925 r. Ukończyła studia medyczne na Uniwersytecie w Genewie. Będąc siostrą zakonną pracowała jako lekarz kolejno w Kozienicach, Wilnie, Nowogródku, Warszawie (w czasie II wojny światowej) i ponownie w Kozienicach. W Kozienicach założyła pierwsze w Polsce Towarzystwo Trzeźwości. Dwukrotnie odznaczona Złotym Krzyżem Zasługi.

${ }^{15}$ Zob. K. D ę b o w s k a, Zgromadzenie, s. 201-202, 223.

${ }^{16}$ Wiele informacji na temat pracy sióstr w szpitalach i innych placówkach medycznych znajduje się w spisanej przez K. Gru s zc z yńs ką Historii Zgromadzenia SS. Franciszkanek od Cierpiacych, oprac. L. Czermińska, J. Marecki, Kraków 2019.

${ }^{17}$ Zob. L. C z e r m i ń s k a, Wszystko zaczęło się, s. 86. 
W jak najlepszym planowaniu i organizowaniu kształcenia sióstr Kazimierze Gruszczyńskiej $\mathrm{z}$ pewnością pomagało wykształcenie pedagogiczne. „Była pedagogiem energicznym, wytrawnym, stanowczym, choć o złotym sercu. Kochała te młodociane latorośle z nowicjatu miłością prawdziwie macierzyńską, nie szczędziła dla nich żadnej troski, żadnego starania [...]"18. Z pewnością doświadczenie pedagogiczne pozwalało jej też właściwie dobierać kadry. „Z pielęgniarek przez nią wybranych, powstała prawdziwa armia osób oddanych swej idei z całym zaparciem i poświęceniem. [...] Oprócz dozoru przy chorych po mieszkaniach obejmować poczęły obsługę szpitali i różnych dobroczynnych zakładów nie tylko w Warszawie, ale i na prowincji. [...] Na placówkach tych podtrzymywały ducha polskiego i katolickiego, przeciwdziałając propagandzie rusyfikacyjnej i prawosławiu [...]"19.

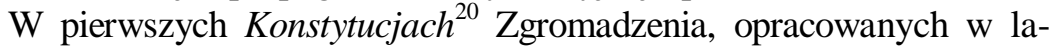
tach 1882-1884 na prośbę Matki Kazimiery Gruszczyńskiej, o. Honorat Koźmiński określił jako powołanie Sióstr Franciszkanek od Cierpiących między innymi poświęcenie się pracy z chorymi w szpitalach i domach ${ }^{21}$. Rozdziały mówiące o duchu poświęcenia i apostolstwa opracowały Kazimiera Gruszczyńska i Magdalena Sasulicz. Widać tam zarówno głębokie współczucie dla cierpiących chorych, jak i nacisk na zapewnienie im opieki duchowej, ale sprawowanej w niezwykle wyważony sposób. Te zapisy także były pomocą dla sióstr, zajmujących się pielęgnowaniem chorych. Trzeba pamiętać, że oprócz przygotowania pielęgniarskiego także praca duchowa, opieka religijna nad chorym były powołaniem sióstr, dlatego w przypadku przygotowania sióstr franciszkanek do pracy pielęgniarskiej nie można pominąć czy zlekceważyć ich misji apostolskiej.

${ }^{18}$ AFC, sygn. E I, T. I-Kr/7, Kronika kaplicy w Kozienicach 1919-1956, In nomine Domini, s. 25.

19 AFC, sygn. C I, T. I-MK/46, I. K o z i e l e w s k i, Życiorys Matki Założycielki, s. 140.

${ }^{20}$ AFC, sygn. A II, T. I-Konst/7, Pierwsza Ustawa ułożona dla Sióstr Cierpiących (Używana od roku 1882 do roku 1909). W artykule wykorzystano tekst odpisu Pierwszej Ustawy: AFC, sygn. A II, T. I-Konst/9, Konstytucje Sióstr Cierpiących.

${ }^{21}$ To przesłanie pozostało także w późniejszych wersjach Konstytucji. Po 1905 r., w trakcie starań o zatwierdzenie Zgromadzenia, tekst dokumentu przerobiono, wykreślając z niego przepisy bezpośrednio adresowane do sióstr zajmujących się opieką nad chorymi. 
W rozdziale zatytułowanym „Duch poświęcenia i najwyższej miłości” czytamy między innymi: „Głównym jej [siostry] zadaniem jest służenie chorym i dlatego tam najpierw będzie objawiać się jej poświęcenie"22. W rozdziale nazwanym „Duch apostolstwa” znajduje się zdanie: „Apostolstwo to jednak powinno być odpowiednie do jej [siostry] życia ukrytego przed światem, a zatem nie może być głośne, jawne, gwałtowne i natarczywe, ale ma być ciche, spokojne, łagodne, cierpliwe, bez ludzkiego pośpiechu i przynaglenia, wyczekujące odpowiedniej chwili, ukryte nawet przed tymi, wobec których się je pełni" ${ }^{23}$.

Od początku w swojej pracy z chorymi, zarówno w szpitalach jak i w domach prywatnych, siostry kierowały się także zaleceniami Matki Kazimiery Gruszczyńskiej, spisanymi w formie swoistego, choć raczej nieformalnego, regulaminu zatytułowanego Informacje o pielęgnowaniu chorych ${ }^{24}$. Przygotowane niewątpliwie w oparciu o znane w Zgromadzeniu podręczniki ${ }^{25}$, ale także odwołujące się do dostępnej w tamtym czasie ogólnej wiedzy z zakresu opieki nad chorymi. Dokument spisany bezpośrednio na użytek Zgromadzenia uwzględniał nie tylko specyfikę pracy sióstr, ale także charyzmat zakonu. Miał także spełniać funkcję instruktażową dla sióstr nieprzygotowanych zawodowo do opieki nad pacjentami. Dla K. Gruszczyńskiej realizacja charyzmatu Zgromadzenia w zakresie opieki nad chorymi łączyła się $\mathrm{z}$ jej osobistym powołaniem, odczuwanym od najmłodszych lat ${ }^{26}$.

I tak w znacznie krótszej części poświęconej pracy w szpitalach, na samym początku napisała, że siostry przede wszystkim muszą się stosować do wewnętrznych, obowiązujących w danej placówce instrukcji. A więc, jak można przypuścić, powinny także z tych instrukcji czerpać dla siebie wiedzę i naukę pomocną w pielęgnowaniu chorych.

Duży nacisk położyła na troskliwe pielęgnowanie chorych oraz na opiekę duchową, religijną, ale sprawowaną dyskretnie, bez narzu-

\footnotetext{
${ }^{22}$ AFC, sygn. A II, T. I-Konst/9, Konstytucje Sióstr Cierpiących, s. 106.

${ }^{23}$ AFC, sygn. A II, T. I-Konst/9, Konstytucje Sióstr Cierpiących, s. 115-116.

${ }^{24}$ AFC, sygn. C I, T. I-MK/12, K. Gru s z c z yń s k a, Informacje o pielęgnowaniu chorych. O traktowaniu przez K. Gruszczyńską dokumentu jako regulaminu świadczą początkowe słowa części poświęconej pracy w szpitalach: „Co do regulaminu w szpitalach, trudno określić, każdy ma swoje instrukcje...”.

${ }^{25}$ Zob. D. O 1 s z e w s k i, W stużbie cierpiącym, s. 97-98.

${ }^{26}$ Zob. J. S t ę p i eń, Rys życia, s. 265.
} 
cania się. Siostry, zwane w dokumencie dozorczyniami, powinny modlić się z chorymi, odmawiać różaniec, także im czytać. „O ile można” dbać, aby przystępowali do spowiedzi, przynajmniej raz po przybyciu do szpitala, także częściej, ale tylko jeśli jest to uzgodnione z kapelanem szpitalnym ${ }^{27}$. „Dozorczyni powinna wszelkimi sposobami starać się przygotować chorego do dobrej śmierci i nie opuszczać go do ostatniego tchnienia, ostatnie chwile powinny bardzo cenić, bo od niej wiele dla duszy zależy. Siostry nie powinny być nigdy felczerkami ale czuwać jak najtroskliwsza matka nad dzieckiem, dla niej nie ma ani dnia ani nocy, jeżeli jedna się czuje zmęczona powinna ją druga zmienić, jak chory niebezpieczny [bliski śmierci] nie opuszczać go. Siostra nie tylko dla duszy ale i dla ciała powinna okazać troskliwość. Jeżeli chory jest po operacji lub w ciężkiej chorobie nie zostawić go samego na noc, bo noc daje cierpienia, ale zmieniać się kolejno"28.

Przy okazji warto zaznaczyć, że K. Gruszczyńska zalecała siostrom w szpitalach nosić strój będący swego rodzaju uniformem, nadający im oficjalny wygląd jej zdaniem najwłaściwszy dla pracy w szpitalu ${ }^{29}$.

W przedmiocie opieki nad chorymi w domach prywatnych rady i zalecenia K. Gruszczyńskiej dla sióstr są znacznie obszerniejsze. To oczywiste, bo dla tego rodzaju opieki nad chorymi nie było instrukcji, do których siostry mogłyby się stosować. Opieka nad chorym w domu była specyfiką Zgromadzenia, można powiedzieć działaniem nowatorskim $\mathrm{w}$ zakresie pielęgnowania chorych $\mathrm{w}$ tamtym czasie ${ }^{30}$. Potrzeba takiej działalności wynikała również często z niskiego zaufania do leczenia szpitalnego i nie najlepszej opieki w szpitalach, choć podkreślić wypada, że umiejętności lekarzy były na dobrym poziomie $^{31}$. Kazimiera Gruszczyńska wychodzi więc naprzeciw oczekiwa-

\footnotetext{
${ }^{27}$ Zob. AFC, sygn. C I, T. I-MK/12, Informacje: na s. 1 czytamy: „[...] były fakty, że księża nie chcieli, a jeden kazał dać znać tylko wtedy, kiedy chory był bliski śmierci, gdy sprowadzony do chorego nie okazującego niebezpieczeństwa robił przykre wymówki".

${ }^{28}$ Tamże, s. 1-1a.

${ }^{29}$ Zob. J. S t ę p i eń, Rys życia, s. 257.

${ }^{30} \mathrm{O}$ opiece nad chorymi w domach wielokrotnie wspomina K. Grus z c z y ńs k a w Historii Zgromadzenia SS. Franciszkanek od Cierpiacych.

31 Zob. E. M a zu r, Szpitale, s. 27, 33-34.; Z. P odgórska-Klawe, Szpitale warszawskie, s. 236, 248-249.
} 
niu społecznemu, traktując opiekę pielęgniarską nad chorymi w domach prywatnych jako niezwykle ważne powołanie sióstr ${ }^{32}$.

Zgodnie z jej zaleceniami, siostry powinny zawsze być gotowe udać się na wezwanie do chorego o każdej porze, po drodze w modlitwie polecając go i jego bliskich opiece Bożej. Opiekę powinny sprawować w duchu cichego apostolstwa, czyli powinny zjednywać chorego swoim poświęceniem, nie okazywać niechęci, znosić cierpliwie i z pogodą ducha ewentualne przykrości, a nawet ofiarować je Panu Bogu na intencję chorego.

Mają dokładnie wypełniać zalecenia lekarza, o niczym nie decydować samodzielnie. Nie powinny narzucać lekarza, ale całkowicie pozostawić wybór choremu lub rodzinie. Powinny utrzymywać porządek w pokoju chorego i dbać o czystość. Jeśli trzeba - przygotować mu odpowiednie posiłki. „Posługi wstydliwe” mają zostawiać bliskim chorego, same mają je wykonywać tylko w ostateczności.

Siostry nie powinny chodzić do apteki ani po sprawunki, chyba że nie ma kto się tym zająć.

K. Gruszczyńska w swoich zaleceniach zdecydowanie zabrania podnoszenia chorych oraz opieki nad sparaliżowanymi i chorymi umysłowo. Wynika to zapewne z jednej strony z troski o bezpieczeństwo i zdrowie sióstr, ale być może także ze świadomości, że wśród tej grupy pacjentów, z oczywistych względów, byłaby utrudniona a nawet niemożliwa praca apostolska.

Po powrocie od chorych siostry powinny wziąć kąpiel, zmienić i zdezynfekować ubranie, aby nie roznosić chorób.

Siostry opiekują się chorymi bez względu na ich wyznanie. Nie mogą jednak uczestniczyć w obrządkach religijnych innych wyznań, jedynie mogą pomóc $\mathrm{w}$ ich przygotowaniu.

Winny zachować ostrożność w doprowadzaniu do przyjęcia chrztu przez osoby nieochrzczone, powinny z tym czekać do „ostatecznej chwili”. Delikatnie i bez nacisków mogą starać się skłaniać zwłaszcza ciężko chorych do spowiedzi i przyjęcia ostatnich sakramentów.

\footnotetext{
32 Świadczy o tym dobitnie fakt, że K. Gruszczyńska nie zgodziła się na usunięcie zapisu o sprawowaniu przez siostry opieki nad chorymi w domach prywatnych, mimo groźby niezatwierdzenia Zgromadzenia jako zakonu przez Stolicę Apostolską w 1909 r. Zob. K. Gr u s z c z y ń s k a, Historia Zgromadzenia, s.75-76.
} 
Sprowadzanie księdza do chorego należy zostawić rodzinie, jedynie w razie pilnej konieczności siostra zajmuje się tym sama.

Jeśli chory jest w ciężkim stanie siostry nie mogą go opuszczać, nie chodzą wówczas do kościoła, a w niedziele i święta na czas nabożeństwa musi je ktoś przy chorym zastąpić. Jeśli chory jest bliski śmierci nawet w czasie rezurekcji i pasterki siostry nie powinny go zostawiać, choć zwyczajowo na czas tych nabożeństw wszystkie powinny się gromadzić w domu zakonnym.

Aby nie stwarzać pretekstów do plotek i nieporozumień ze służbą domową siostry powinny jak najmniej się komunikować. Winny zachowywać dyskrecję, nie opowiadać o domach gdzie pracują, na te tematy mogą rozmawiać jedynie z siostrą do tego wyznaczoną.

Nie powinny u chorych czytać, bo mogłoby to prowadzić do zaniedbywania obowiązków. Chorzy mogliby także prosić o niewłaściwą lekturę. Natomiast, jeśli czas pozwala i lektura jest odpowiednia, czasami mogą czytać choremu.

Po zakończeniu opieki nad chorym siostry z zasady nie mogą utrzymywać z nim dalszych kontaktów, „stają się nieznane z chwilą wyjścia od chorego". Nie wolno im także przyjmować upominków, ani osobistego wynagrodzenia za opiekę.

Zmiana opiekunek każdorazowo powinna być rozstrzygana indywidualnie, tym bardziej, że chory przyzwyczaja się do określonej siostry i próba zmiany może powodować konflikty.

Kończąc i podsumowując omawiany dokument K. Gruszczyńska pisze: „Ogólnych zasad nie można określić, bo w każdym domu inną metodą",33. Tak więc zarówno do kwestii opieki medycznej jak i niesionej chorym pomocy duchowej siostry powinny podchodzić indywidualnie, jednak przestrzegając pewnych ogólnie nakreślonych reguł.

Jeśli chodzi o zalecenia odnoszące się bezpośrednio do opieki medycznej, warunków higienicznych czy zakresu obowiązków pielęgniarki widać, że autorka, choć sama nie miała zawodowego przygotowania medycznego, ma orientację w ówczesnych tendencjach i wskazówkach lekarskich w tej materii ${ }^{34}$.

${ }^{33}$ AFC, sygn. C I, T I-MK/12, Informacje, p. 23.

${ }^{34}$ Zob. Z. P o d g ó r s k a - K l a w e, Szpitale warszawskie, s. 199-222, 243-258. 
Oprócz Informacji o pielęgnowaniu chorych dla sióstr K. Gruszczyńska napisała także Regulamin dla Domu św. Józefa ${ }^{35}$, przeznaczony dla założonego przez Zgromadzenie w 1910 roku szpitala. Praktyczne rady dotyczące opieki nad chorymi znaleźć można także w innych tekstach K. Gruszczyńskiej - listach, zaleceniach powizytacyjnych, przemówieniach $^{36}$. Wszystkie pisma pokazują, że oparte są nie tylko na wiedzy teoretycznej, ale są efektem praktyki i głębokich przemyśleń Matki Kazimiery w tym zakresie. Wszystkie odnoszą się też do sfery duchowej, religijnej. Kładą nacisk na zachowanie cierpliwości i głębokiego współczucia względem chorych i cierpiących.

Nie możemy zapominać, że osoby, do których kierowane były rady i zalecenia były przede wszystkim siostrami zakonnymi. Dlatego nie powinno dziwić, że we wszystkich dokumentach, co najmniej tak samo ważna jak opieka pielęgniarska była troska i opieka duchowa nad pacjentem.

Zgromadzenie Sióstr Franciszkanek od Cierpiących bardzo mocno odwoływało się do duchowości franciszkańskiej, przez metaforę cierpiącego Chrystusa odnosiło się do cierpienia człowieka. Z tej właśnie duchowości wywodzi się apostolat posługi cierpiącym, podstawowy dla Zgromadzenia, wyrażany wielokrotnie w Konstytucjach i innych dokumentach. Szczególnie podkreślany w tych fragmentach, które K. Gruszczyńska przygotowała osobiście. Czytamy tam między innymi, że siostry powinny przyjąć jak swoje siostry i braci wszystkich cierpiących, zwłaszcza chorych, oddając im posługi zarówno w stosunku do ciała jak i duszy. Ich rolą jest poświęcenie się dla chorych i cierpiących, którymi się opiekują, kosztem własnej wygody a nawet zdrowia i życia. Ich apostolstwo ma być ,,apostolstwem ofiary i cierpienia”37.

K. Gruszczyńska starała się wpoić siostrom szacunek dla cierpienia i cierpiącego człowieka. Nakazywała patrzeć na chorego przez pryzmat cierpiącego Chrystusa i miłości, jaką powinny żywić przez Niego do

\footnotetext{
${ }^{35}$ AFC, sygn. D I, T. I-San/9, Regulamin Sanatorium Św. Józefa ułożony przez Matkę Kazimierę.

${ }^{36}$ Wszystkie te dokumenty przechowywane są w Archiwum Sióstr Franciszkanek od Cierpiących, w zespołach akt: C I, T. I-MK, II-MK, III-MK, IV-MK.

${ }^{37}$ D. O l s z e w s k i, W stużbie cierpiącym, s. 93-98; zob. także: L. C z e r m i ń s k a, Duchowość Sióstr Franciszkanek od Cierpiacych. Studium na podstawie dokumentów Zgromadzenia, Łódź 2009, s. 214-224.
} 
chorych. Przestrzegała je przed rutyną i mechanicznym wykonywaniem obowiązków, chciała, by były prawdziwymi ,siostrami cierpiących"38.

Apostolski aspekt pracy sióstr przy chorych znajdował silne odzwierciedlenie w działaniach, które K. Gruszczyńska podejmowała w celu kształcenia i ugruntowania właściwej postawy sióstr ${ }^{39}$. Troszczyła się, by odpowiednie rozumienie misji apostolskiej Zgromadzenia realizowane było przez siostry w ich codziennej pracy. Podczas wizytacji placówek, w których siostry pracowały zwracała na to baczną uwagę i w swoich zaleceniach powizytacyjnych często podkreślała konieczność całkowitego poświęcenia się na rzecz podopiecznych, uważała opiekę nad chorymi za najważniejsze zadanie. Zwiedzała sale chorych, rozmawiała z nimi, szczegółowo przyglądała się pracy pielęgniarskiej sióstr. Także te pracujące w domach prywatnych codziennie po powrocie od chorego zdawały Matce sprawozdanie $\mathrm{z}$ dyżuru ${ }^{40}$.

Niedługo po powstaniu Zgromadzenia potrzeby w zakresie pielęgnowania chorych zaczęły przerastać możliwości. Zaczęto odczuwać wyraźny brak sióstr do opieki nad chorymi, zarówno w domach jak i w szpitalach czy ambulatoriach. W latach 90. XIX wieku siostry opiekowały się rocznie około 1000 chorych w pięciu szpitalach, pracowały w trzech ambulatoriach, w domach prywatnych opiekowały się około 50 pacjentami rocznie ${ }^{41}$.

Mimo wysiłków bardziej doświadczonych w pielęgniarstwie i posiadających przygotowanie medyczne sióstr w przekazywaniu wiedzy pozostałym, K. Gruszczyńska ciągle dostrzegała braki w przygotowaniu zawodowym opiekunek. Dlatego zainicjowała zorganizowanie, prowadzonych przez lekarzy związanych ze Zgromadzeniem, kursów zawodowych dla sióstr, w ramach których zdobywały niezbędną wiedzę z zakresu anatomii i fizjologii. Kursy takie odbyły się w 1908 i 1918 roku w Wilnie i Warszawie, w zajęciach mogły uczestniczyć

\footnotetext{
${ }^{38}$ L. C z e r m iń s k a, Wszystko zaczęło się, s. 91.

${ }^{39}$ Zob. K. D ę b o w s k a, Zgromadzenie, s. 203, 214-216.

${ }^{40}$ Zob. AFC, sygn. C I, T. II-MK/63, Wspomnienia o Matce Gruszczyńskiej, by z nią obcować wewnętrznie siostry Janiny Pogorzelskiej; D. Ols ze w s ki, W stużbie cierpiącym, s. 99-100; J. S t ę p i e ń, Rys życia, s. 258; L. C z e r m i ń s k a, Wszystko zaczęto się, s. 90.

${ }^{41}$ Zob. K. D ę b o w s k a, Zgromadzenie, s. 197-198.
} 
wszystkie siostry, także te bezpośrednio nie pracujące przy chorych, kurs kończył się egzaminem sprawdzającym zdobytą wiedzę ${ }^{42}$.

W 1935 roku wydano Ustawę o pielęgniarstwie, uzupełnioną w 1936 roku o przepisy wykonawcze. Nakładała ona na wszystkie osoby wykonujące pracę pielęgniarską obowiązek odpowiedniego przygotowania zawodowego. Od tego czasu Siostry Franciszkanki od Cierpiących przygotowywały się do zawodu w państwowych szkołach pielęgniarskich. Cały czas jednak nie zapominano o kursach dokształcających organizowanych dla sióstr ${ }^{43}$. W 1947 roku Zgromadzenie otworzyło własną szkołę pielęgniarską, w której uczyć mogły się także osoby świeckie ${ }^{44}$. Zrealizowano w ten sposób plany i zamierzenia K. Gruszczyńskiej w zakresie powołania szkoły pielęgniarskiej działającej głownie na potrzeby Zgromadzenia.

W Polsce termin ,pielęgniarka” na określenie osoby opiekującej się, pielęgnującej chorych pojawia się na przełomie XIX i XX wieku, nieco później niż w krajach zachodniej Europy ${ }^{45}$. Pierwsza w świecie świecka szkoła pielęgniarska powstaje w 1860 roku w Londynie, wówczas też zaczyna się tworzyć model zawodowy pielęgniarki jako osoby fachowo wspomagającej pracę lekarza ${ }^{46}$. W Polsce do końca XIX wieku pielęgnowaniem chorych w szpitalach zajmowały się często siostry zakonne, jednak w formie działalności nie zawodowej a dobroczynnej, wynikającej z posłannictwa danego zgromadzenia.

Nauczanie pielęgniarstwa odbywało się wówczas w formie kursów i szkoleń dających wiedzę i umiejętności potrzebne osobom spełniającym jedynie funkcje pomocnicze ${ }^{47}$. W formie kursów nauka odbywała się także w pierwszej na ziemiach polskich, powstałej przy Szpitalu Powszechnym we Lwowie w 1895 roku, szkole dla „dozorczyń chorych", kształcącej pielęgniarki zakonne i świeckie ${ }^{48}$. W 1911 roku,

\footnotetext{
${ }^{42}$ Zob. tamże, s. 223; J. S t ę p i e ń, Rys życia, s. 256; L. C z e r m i ń s k a, Wszystko zaczęło się, s. 87.

43 Zob. K. D ę b ow s k a, Zgromadzenie, s. 224; AFC, sygn. C I, T. IV-MK/110, Listy [Kazimiery Gruszczyńskiej] do osób świeckich, przyjaciół i dobrodziejów, List do dr Hordyńskiego [1925] (L. 7).

${ }^{44}$ Zob. K. D ę b o w s k a, Zgromadzenie, s. 202, 225; J. S t ę p i e ń, Rys życia, s. 272.

45 Zob. T. S los or z, Kształcenie zawodowe pielęgniarek $w$ ujęciu historycznym, „Polski Przegląd Nauk o Zdrowiu”, 2014, nr 4 (41), s. 298.

${ }^{46}$ Zob. tamże, s. 298.

${ }^{47}$ Zob. tamże.

${ }^{48}$ Zob. tamże, s. 299.
} 
przy poparciu lekarzy ze środowiska Uniwersytetu Jagiellońskiego, otwarto w Krakowie Szkołę Zawodowych Pielęgniarek Panien Ekonomek św. Wincentego a Paulo, gdzie po teoretycznym kursie przedmiotów zawodowych słuchaczki uczestniczyły w praktyce zawodowej na oddziałach szpitalnych.

Nauka trwała początkowo półtora roku, później dwa lata. Wykłady w szkole prowadzili i nadzór nad praktykami sprawowali wykładowcy uniwersyteccy. Szkoła działała do 1921 roku, z przerwą w latach 1914-1918, i istotnie przyczyniła się do rozwoju zawodowego pielęgniarstwa w Polsce ${ }^{49}$.

W Warszawie od końca XIX wieku prowadzone były szkolenia dla kobiet chcących się poświęcić pielęgnowaniu chorych, jednak dopiero w 1905 roku powstała jednoroczna Szkoła Pielęgniarstwa Aleksandra Fruchtmana, kształcąca także praktycznie. Pierwsza z prawdziwego zdarzenia szkoła pielęgniarska powstała w Warszawie dopiero w 1921 roku z inicjatywy władz miasta, Wydziału Lekarskiego Uniwersytetu Warszawskiego, PCK oraz Ministerstwa Zdrowia Publicznego. Była to Warszawska Szkoła Pielęgniarstwa, pierwsza powstała w kraju po odzyskaniu przez Polskę niepodległości. Szkoła dysponowała salami wykładowymi, salami do ćwiczeń, a także internatem dla słuchaczek ${ }^{50}$.

Przy licznych szpitalach funkcjonujących na ziemiach polskich, poczynając od początku XX wieku, również działały szkoły, towarzystwa i kursy przygotowujące pielęgniarki do pracy, często łączące zajęcia teoretyczne ze szkoleniem praktycznym na oddziałach szpitalnych ${ }^{51}$.

Wynikająca $\mathrm{z}$ ofiarności i poświęcenia w pracy z chorymi popularność sióstr franciszkanek powodowała, że ilość wezwań do chorych przewyższała możliwości personalne Zgromadzenia ${ }^{52}$. To uświadomiło K. Gruszczyńskiej konieczność koncentrowania działalności przede

\footnotetext{
${ }^{49}$ Zob. tamże, s. 299; H. M a t o g a, Miłosierdzie, które dało początek pielęgniarstwu, „Małopolskie Pielęgniarki i Położne”, 2015, nr 17, s. 2-3; A. M a j d a, J. Z a l e w $\mathrm{s} \mathrm{k}$ a - P u c h a ł a, Stuletnia tradycja kształcenia pielęgniarek $w$ Krakowie, „Problemy Pielęgniarstwa”, 2012, nr. 20 (1), s. 94-95.

${ }^{50}$ Zob. T. S 1 o s or z, Ksztatcenie zawodowe pielegniarek, s. 299-300.

${ }^{51}$ Zob. tamże, s. 299-300.

${ }^{52}$ Jak pisała K. Gruszczyńska: „Siostry dość szybko zyskały sobie zaufanie tak w społeczeństwie jak również i u lekarzy jako troskliwe pielęgniarki. Wzywali bez wyjątku wyznań...”. K. G r u s z c z y ń s k a, Historia Zgromadzenia, s. 55; zob. także: AFC, sygn. C I, T. II-MK/67, H. Władzińska, Wspomnienia, s. 47.
} 
wszystkim na tym zadaniu. Aby lepiej przygotować siostry do obowiązków zamierzała otworzyć szkołę pielęgniarską, w tym celu wysłała w 1907 roku dwie siostry do Hamburga na roczny kurs pielęgniarski, gdzie miały się kształcić w zawodzie, a po powrocie zasilić kadry planowanej szkoły ${ }^{53}$. Chciała też rozszerzyć działalność Zgromadzenia na opiekę nad chorymi na wsiach ${ }^{54}$.

W 1907 roku z inicjatywy Kazimiery Gruszczyńskiej powołane zostało Towarzystwo Opieki nad Pielęgniarkami pod wezwaniem św. Józefa, zrzeszające wyłącznie Siostry Franciszkanki od Cierpiących $^{55}$. W 1919 roku zostało ono przekształcone w Towarzystwo Pielęgnowania Chorych pod wezwaniem św. Józefa. Natomiast w 1920 roku do Towarzystwa zostało włączone "Przytulisko",56 i powstało wówczas Towarzystwo Pielęgnowania Chorych św. Józefa - Przytulisko $^{57}$. K. Gruszczyńska, wykorzystując sprzyjającą sytuację po wydaniu w 1905 roku ukazu tolerancyjnego, pragnęła w ten sposób sformalizować działalność Zgromadzenia oraz zapewnić mu trwałe i bezpieczne podstawy funkcjonowania. Odtąd zyskuje ono, jako towarzystwo, podstawy prawne działalności wobec władz świeckich, wobec władz kościelnych pozostając zgromadzeniem życia ukrytego ${ }^{58}$.

Zob. AFC, sygn. C I, T. IV-MK/110, Listy, Listy do hrabiów Kronnenbergów (L. 19, 20), 18 XI 1908, 27 XII 1908; List do hr. E. Plater (L. 21), 20 III 1908; Listy do Szejblerów w Łodzi (L. 42), 5 VII 1908; AFC, sygn. C II, T. II-MŁ/34, Historia domu Sanatorium św. Józefa Warszawa, s. 2; K. D ę b o w s k a, Zgromadzenie, s.199, 223; J. S t ę p i e ń, Rys życia, s. 250, 256; L. C z e r m i ń s k a, Wszystko zaczęło się, s. 87.

54 Zob. AFC, sygn. C I, T. IV-MK/110, Listy, List do hr. E. Plater (L. 21), 20 III 1908.

${ }^{55}$ Zob. K. Gru s z c z yń s k a, Historia Zgromadzenia, s. 113-115; K. D ę b o w s k a, Zgromadzenie, s. 196; L. C z e r m i ń s k a, Wszystko zaczęło się, s. 58.

${ }^{56}$ Instytucja dobroczynna założona w 1858 roku w Warszawie z inicjatywy członków róż różańcowych. K. Gruszczyńska została przełożoną „Przytuliska” w 1882 r. Zob. K. Gruszczyńska, Historia Zgromadzenia, s. 27 i nast.; K. D ę b o w s k a, Zgromadzenie, s. 163 i nast.

${ }^{57}$ W 1947 r. do Towarzystwa przyłączono Towarzystwo Opieki nad Ubogimi Matkami i ich Dziećmi „Macierzyństwo”. W 1949 r. Towarzystwo zostało zlikwidowane po rejestracji Zgromadzenia Sióstr Franciszkanek od Cierpiących zgodnie z obowiązującymi wówczas przepisami prawa. Zob. K. D ę b o w s k a, Zgromadzenie, s. 197.

${ }^{58}$ Zob. K. G r u s z c z y ń s k a, Historia Zgromadzenia, s. 113-115; L. C z e r m i ń s k a, Wszystko zaczęto się, s. 58-59; K. D ę b ow s k a, Zgromadzenie, s. 196-198; J. S t ę p i e ń, Rys życia, s. 270-271. Por. także AFC, sygn. C I, T. IV-MK/110, Listy, Listy do hrabiów Kronnenbergów (L. 19, 20), 18 XI 1908, 27 XII 1908; List do hr. Mikołaja Sobańskiego (L. 34), 6 III 1909; Listy do Szejblerów w Łodzi (L. 42), 5 VII 
Statut dawał Towarzystwu uprawnienia do zakładania szpitali, ambulatoriów i prowadzenia szkół pielęgniarskich. Do organizowania kursów, wykładów i praktyk zawodowych dla pielęgniarek w szpitalach i ambulatoriach publicznych i prywatnych oraz założonych przez Towarzystwo, których uczestniczki poznawały najnowsze metody pracy pielęgniarki. Do pośredniczenia w znajdowaniu pracy dla pielęgniarek, oraz do wspomagania ich materialnie w razie potrzeby ${ }^{59}$.

To wszystko miało się przyczynić do stworzenia możliwości lepszego wykształcenia sióstr w zakresie pielęgnowania chorych, a to z kolei prowadzić do dalszego rozwoju Zgromadzenia, a co za tym idzie do zaspokajania w coraz szerszej skali potrzeb w zakresie opieki nad chorymi w domach oraz szpitalach i innych placówkach.

Dzięki możliwościom, jakie zyskało Zgromadzenie po założeniu Towarzystwa realne stawało się zrealizowanie kolejnego zamysłu K. Gruszczyńskiej - budowy własnego szpitala, który nie tylko dawałby opiekę chorym, ale także bardzo dobrą okazję siostrom do praktycznego uzupełnienia pod okiem fachowych lekarzy i pielęgniarek zdobytej wiedzy teoretycznej $^{60}$.

Kazimiera Gruszczyńska doskonale zdawała sobie sprawę zarówno z nienajlepszych warunków zarówno higienicznych jak i w zakresie opieki nad chorymi, panujących w szpitalach na przełomie XIX i XX wieku. Miała także świadomość, że liczba wykwalifikowanych pielęgniarek w stosunku do potrzeb jest dalece niewystarczająca. Wnioski takie łatwo można było wyciągnąć choćby na podstawie codziennej pracy sióstr. I właśnie powołanie Towarzystwa miało przynajmniej w pewnym stopniu zaradzić tym trudnościom poprzez otwarcie własnego szpitala i szkoły pielęgniarskiej, łączących kształcenie teoretyczne z praktycznym. K. Gruszczyńska wierzyła, że w ten sposób uda się zapewnić siostrom odpowiedni poziom wykształcenia w zakresie pielęgniarstwa.

1908; K. Gr u s z c z y ń s k a, Historia Zgromadzenia, s. 117; AFC, sygn. C I, T. IIMK/75, Wspomnienia o śp. Matce Kazimierze Gruszczyńskiej skreślone przez mec. Waleriana Strzałkowskiego Radcę Prawnego Zgromadzenia od 1905 r. do końca [swego] życia, tj. 1953, s. 3-4; AFC, sygn. C I, T. I-MK/46 I. K o zi e l e w s k i, Życiorys Matki Założycielki, s. 158-160.

${ }^{59}$ Zob. K. D ę b o w s k a, Zgromadzenie, s. 197-198; J. S t ę p i e ń, Rys życia, s. 271.

${ }^{60}$ Zob. AFC, sygn. C I, T. IV-MK/110 Listy, Listy do hrabiów Kronnenbergów (L. 19, 20), 18 XI 1908, 27 XII 1908; List do hr. E. Plater (L. 21), 20 III 1908; Listy do Szejblerów w Łodzi (L. 42), 5 VII 1908; J. S t ę p i e ń, Rys życia, s. 271-272. 
Ze środków własnych i darowizn ${ }^{61}$ w latach 1909-1910 Zgromadzenie wybudowało przy ul. Hożej $80 \mathrm{w}$ Warszawie szpital, tak zwane „Sanatorium”. Zbudowany i urządzony zgodnie z najnowszymi wymogami i wiedzą medyczną stał się jednym z najnowocześniejszych w tamtym czasie w Warszawie. Posiadał oddziały wewnętrzny i chirurgiczny łącznie dla 50 pacjentów ${ }^{62}$.

K. Gruszczyńska podejmując trud budowy szpitala i zabiegając o pozyskanie środków na ten cel, podkreślała, że mimo iż od lat siostry poświęcają się opiece nad chorymi, wciąż brak im dostatecznej do potrzeb ilości wykwalifikowanych pielęgniarek ${ }^{63}$. Wobec niezrealizowania do 1947 roku zamiaru powołania szkoły pielęgniarskiej, stał się on na długie lata podstawową placówką szkoleniową dla sióstr ${ }^{64}$.

Jak już wspomniano, K. Gruszczyńska sama ułożyła procedury dla szpitala zatytułowane Regulamin dla Domu św. Józefa. W początkowym okresie wiele też czasu wspólnie z siostrami poświęciła na jego urządzenie i wprowadzenie określonych zasad opieki nad chorymi ${ }^{65}$.

W związku z trudną sytuacją polityczno-społeczną kraju, brakami personalnymi i trudnościami finansowymi Zgromadzenia, Kazimiera Gruszczyńska z czasem odeszła od idei zakładania własnej szkoły pielęgniarskiej ${ }^{66}$. Skoncentrowała się na rozbudowie szpitala. Cieszył się on takim powodzeniem wśród chorych, że w 1916 roku konieczna była jego rozbudowa poprzez dobudowanie piętra nad pawilonem chirurgicznym. Kolejną rozbudowę przeprowadzono już po śmierci K. Gruszczyńskiej w 1933 roku $^{67}$.

${ }^{61}$ Zob. tamże, List do hr. Władysława Grocholskiego (L. 5), 20 VI 1909; List do hr. Józefa Przeździeckiego (L. 22), b.d.; Listy do Szejblerów w Łodzi (L. 42), 5 VII 1908.

${ }^{62}$ Zob. AFC, sygn. C II, T. II-MŁ/34, Historia domu Sanatorium św. Józefa Warszawa ul Hoża 80 [spisana przez Matkę Magdalenę Łazowską], b.d.; także AFC, sygn. C I, T II/75, Wspomnienia o śp. Matce Kazimierze Gruszczyńskiej, s. 4; J. S t ę p i e ń, Rys życia, s. 272-273; K. D ę b o w s k a, Zgromadzenie, s 199-200.

63 Zob. AFC, sygn. C I, T. IV-MK/110 Listy, Listy do hrabiów Kronnenbergów (L. 19, 20), 18 XI 1908, 27 XII 1908.

${ }^{64}$ Zob. L. C z e r m i ń s k a, Wszystko zaczęło się, s. 87.

${ }^{65}$ Zob. J. S t ę p i eń, Rys życia, s. 272.

${ }^{66}$ Dopiero w 1947 r. udało się zrealizować zamiar K. Gruszczyńskiej i otworzyć szkołę pielęgniarską. Zob. K. D ę b o w s k a, Zgromadzenie, s. 202.

${ }^{67}$ Zob. J. S t ę p i eń, Rys życia, s. 272. 
Choć były w nim zarezerwowane łóżka dla ubogich, to jednak był szpital przede wszystkim placówką dla ludzi zamożnych, których stać było na opłacenie leczenia ${ }^{68}$. I nic w tym dziwnego, był przecież źródłem dochodu dla Zgromadzenia. Siostry utrzymywały się także $\mathrm{z}$ wynagrodzenia za pracę $\mathrm{w}$ innych placówkach medycznych oraz przy chorych $w$ domach ${ }^{69}$.

Związany ze Zgromadzeniem dr Józef Kizler w 1927 roku na łamach „Przeglądu Katolickiego" 70 pisał, że przed niemal 50 latami inicjatywa profesjonalnego wykształcenia i przygotowania pielęgniarek do opieki nad chorymi należała do K. Gruszczyńskiej. Siostry ze Zgromadzenia Sióstr Franciszkanek od Cierpiących zgodnie z zamysłem i pod nadzorem swojej przełożonej kształciły się i przygotowywały do zawodu w kraju i za granicą, co dało im fachowe i cenione umiejętności do pracy w różnych placówkach leczniczych i domach prywatnych w Warszawie i wielu innych miastach.

I ta opinia warszawskiego lekarza niech będzie podsumowaniem działalności Matki Kazimiery Gruszczyńskiej, prowadzącej do zapewnienia siostrom franciszkankom jak najlepszego wykształcenia w zakresie pielęgniarstwa. Działalności, podkreślmy, realizowanej w czasach pionierskich dla zawodowego kształcenia pielęgniarek.

${ }^{68}$ Zob. K. Dę b ow sk a, Zgromadzenie, s. 200; J. S tę p i én, Rys życia, s. 272. W 1947 r. szpital upaństwowiono, stał się wówczas lecznicą Ministerstwa Zdrowia.

${ }^{69}$ Zob. K. D ę b ow s k a, Zgromadzenie, s. 213.

${ }^{70}$ „Przegląd Katolicki”, nr 38, 1927. 


\section{ANEKS}

Niedatowany dokument zatytułowany: „Informacje o pielęgnowaniu chorych dla sióstr ułożone przez Matkę Kazimierę", spisany został własnoręcznie przez m. Kazimierę Gruszczyńską na siedmiu niepaginowanych kartach o wymiarach 134 x 209 mm (jedna karta pojedyncza oraz trzy numerowane bifolia) z papieru maszynowego, kratkowanego, obecnie w kolorze kremowym.

Karty zapisane są dwustronnie tekstem w jednej kolumnie, zapewne atramentem żelazowo-gallusowym obecnie w kolorze czarnym. $\mathrm{Na}$ kartach znajdują się nieliczne dopiski oraz podkreślenia i przekreślenia wykonane ołówkiem.

Stan zachowania stabilny, ale na wszystkich kartach widoczne są ślady dawnych złożeń, i w tych miejscach występują utrwalone uszkodzenia papieru - pęknięcia, przetarcia, przedarcia. Część kart ma pozaginane narożniki, na ostatniej karcie w skrzyżowaniu złożeń powstały niewielkie ubytki papieru.

Pisownia oraz interpunkcja tekstu źródłowego została zmodernizowana, zachowano jednak charakterystyczne cechy języka autorki, a także składnię i stylistykę wypowiedzi, nieliczne skróty rozwiązano (np. $\mathrm{S}^{\mathrm{a}}-$ siostra, X. - ksiądz).

Ireneusz Ihnatowicz, Projekt instrukcji wydawniczej dla źródet historycznych XIX i początku XX wieku, „Studia Źródłoznawcze”, t. 7, 1962, s. 99-124.

\section{TEKST ŹRÓDŁOWY}

AFC, sygn. C I s T. I/12 - Matka Kazimiera, Informacje o pielęgnowaniu chorych dla sióstr ułożone przez Matkę Kazimierę, b.d., akta luźne, rękopis, s. nlb. 14. 


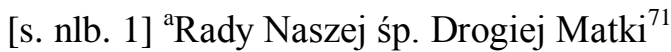

W szpitalach - Co do regulaminu w szpitalach, trudno określić. Każdy ma swoje instrukcje, do których my musimy się stosować.

Dozorczyni odmawia rano, wieczór pacierz z chorymi, o ile może i w ciągu dnia pomodli się z nimi, odmówi różaniec, poczyta im.

O ile można stara się, aby każdy chory przyszedłszy do szpitala był u spowiedzi, częstokroć przy tym jednym korzysta więcej, czasem (zależy od duchowieństwa) wprowadzają spowiedź miesięczną, nie można tego jednak wziąć w zasadę, bo były fakta, że księża nie chcieli i tylko wtedy kazał dać znać jak chory był bliski śmierci, jak był sprowadzony do chorego nie okazującego niebezpieczeństwa robił przykre wymówki.

Dozorczyni powinna wszelkimi// [s. nlb. 2] sposobami starać się przygotować chorego do dobrej śmierci, i nie opuszczać go do ostatniego tchnienia, ostatnie chwile powinny $b$ [ardzo] cenić, bo od niej wiele dla duszy zależy [ss].

Siostry nie powinny być nigdy felczerami, ale czuwać jak najtroskliwsza matka nad dzieckiem, dla niej nie ma dnia ani nocy, jeżeli jedna się czuje zmęczona powinna ją druga zmienić, jak chory niebezpieczny nie opuszczać go.

Siostra nie tylko dla duszy ale i dla ciała powinna okazać troskliwość, jeżeli chory jest po operacji lub w ciężkiej chorobie nie zostawić go samego na noc bo noc dodaje cierpienia, ale zmieniać się kolejno.//

[s. nlb. 3] O dyżurach w domach prywatnych.

1.) Pod względem usposobienia wewnętrznego powinna iść w duchu ustawy, być zawsze gotową na dane jej polecenie, choćby to w nocy gdy dopiero zasnęła chętnie, wesoło dążyć na miejsce wskazane. Drogą niejako przygotowywać się do spełnienia swego zadania polecając w duchu chorego całe otoczenie Bogu. Apostolstwo jej ma być ciche, nie słowami, naukami lecz poświęceniem swoim zjednywać sobie chorego, a choćby chory okazał się najprzykrzejszy nie okazać mu goryczy, nie robić wymówek ale zachować niezamąconą pogodę na twarzy, a doznane przykrości ofiarować na jego intencję (były fakta, że gdy// [s. nlb. 4] żadne wpływy nie okazały się skutecz-

71-a Dopisane ołówkiem, charakter pisma m. Magdaleny Lazowskiej. 
nymi, dobierali różnych kapłanów, nawet arcybiskup przyjeżdżał i ten nie był przyjęty, chcąc wprowadzić kapłana wyjednali pozwolenie aby Msza św. odbyła się przy chorym, i na to się nie zgodził, a śmierć widocznie szybko się zbliżała, zdawało się że już wszystko wyczerpane. Siostra nasza nie brała innego udziału, tylko się w cichości modliła, i ile jej siły starczyły otaczała go opieką, nie okazując nigdy zniechęcenia. Jednej nocy już był bliskim skonania, mówi do niej „Siostro, tyś taka dobra dla mnie, czym ja ci to wynagrodzę". Wtedy ona drżąc z radości i bojaźni ze łzami// [s. nlb. 5] przedstawi[a] mu czym by ją uszczęśliwił, przedstawia mu to szczęście w pojednaniu się z Bogiem. Oburzył się na razie, kazał zaprzestać tej mowy, jednakże w parę godzin zawołał „Siostro, masz rację, sprowadź mi księdza”, i dalej sam dodaje ,jam nie przyjął proboszcza, trzeba to nagrodzić, jego poproś". Spowiadał się dwa razy i najprzykładniej umarł. Podobnych faktów miałyśmy wiele. Jeden wielce uczony wyrzucał księży jednego za drugim. Siostrze wymyślał jak mu się tylko podobało, ta zawsze pogodnie robiła dalej co do niej należało, w końcu ten chory mówi co to jest, ja Pani wymyślam, a Pani zawsze pogodna, niech mi Pani powie czym się odwdzięczę. Ona wtedy swe pragnienie przedstawiła// [s. nlb. 6] i dał się przekonać. Wieleby tym podobnych zdarzeń przytoczyć można. Nawracanie z góry zniechęca często.

2.) Sprowadzanie księdza do chorego zostawia się u nas rodzinie, służbie, a w razie koniecznym to już nie bywa wyboru, choćby o północy sama idzie do księdza. ${ }^{a}$

3.) Posługi wstydliwe ile można według zasad pierwsza w tym ma być rodzina, służba, w konieczności muszą same, piszę to z praktyki się okazuje $[s s]$. $^{\mathrm{b}}$

4.) Dźwigać chorych nie wolno, na to posłuszeństwem obowiązuję. ${ }^{c}$

5. Do sparaliżowanych i cierpiących umysłowo nie chodzą wcale.

6. Ze służbą mają wychodzić uprzejmie, nie wdając się// [s. nlb. 7] w żadne gawędy, nie dlatego aby stronić, doświadczenie wykazało, że

\footnotetext{
${ }^{a} Z$ lewej strony pionowa kreska wzdtuż tekstu punktu 2.

${ }^{\mathrm{b}}$ Z lewej strony pionowa kreska wzdtuż tekstu punktu 3 oraz cały tekst przekreślony wzdtuż ołówkiem.

${ }^{\mathrm{c}}$ Z lewej strony pionowa kreska wzdluż tekstu punktu 4 oraz cały tekst przekreślony wzdtuż ołówkiem.

${ }^{\mathrm{d}}$ Z lewej strony pionowa kreska wzdluż tekstu punktu 5 oraz caly tekst przekreślony wzdłuż ołówkiem.
} 
z tego są nieporozumienia i plotki, nie mają wysłuchiwać skarg na państwa i na odwrót.

7.) Do aptek mają wzbronione chodzić, jak również po sprawunki (naturalnie, że ostatecznie musi być wyjątek jak nie ma komu). ${ }^{\mathrm{e}}$

8.) Czytywać książek, pism u chorych wzbronione, i wprost mają na to thumaczenie, że nie wolno, tłumaczą się tym, że mogłyby być, które by to $b$ [ardzo] lubiły i przez to zaniedbywały swój obowiązek. A rzeczywiście znam ten cel, że mogliby narzucać romansidła i musiałyby czytać. Czasem czytają choremu, ale muszę wpierw// [s. nlb. 8] wiedzieć gdzie? co?

9.) Nie wolno na dyżurach opowiadać o innych dyżurach, i wprowadza się to, że na pytanie gdzie były, u kogo? odpowiadają, że nam wzbronione opowiadać, po prostu dlatego, aby nie roznosić plotek $\mathrm{z}$ domu do domu. Naprowadziło mnie na to fakta, że pytając gdzie była poprzednio odpowiedzią swą wywołała całą przeszłość, charaktera i tylko sobie zamętu narobiła [ss]. Teraz wprost mówię, że „nie wolno opowiadać", i w ogóle nasze dozorczynie mają odpowiad[ać] nie wiem, albo nie wolno. Już są znane z tego i uznają to za dobre, bo daje to rękojmię, że im dają rękojmię, że i o nich mówić nie będą.//

[s. nlb. 9] 10.) W domu nie wolno opowiadać co się dzieje u chorych gdzie jest która, mają obowiązek drobiazgowego zdania sprawy przed siostrą, która do tego upoważniona.

11.) Do kościoła nie wychodzą póki chory nie ma się lepiej, i to z wiedzą i zgodnością chorego. Nie wolno wychodzić raniutko licząc, że chory w tej porze na pewno śpi, bo może obudzić się i przerazić nie wiedząc co się z dozorczynią stało. Gdy chory ma się źle, a w niedzielę lub święto nie ma, albo nie chce ktoś z rodziny zastąpić, wtedy idzie druga siostra $\mathrm{z}$ domu i ten czas zastąpi dozorczynię. ${ }^{\mathrm{a}}$

12.) Na rezurekcję i pasterkę staram się wszystkie w domu mieć, wtedy naprzód uprzedzają rodzinę aby// [s. nlb. 10] się odpowiednio urządzili, ale i tu były już wyjątki, jak chory okazywał się bliski skonu już go siostra nie opuściła.

\footnotetext{
${ }^{\mathrm{e}} Z$ lewej strony pionowa kreska wzdluż tekstu punktu 7 oraz caly tekst przekreślony wzdluż ołówkiem.

${ }^{a}$ Z lewej strony pionowa kreska wzdluż tekstu punktu 11 na dlugości dwóch wersów tekstu.
} 
13.) Jak wracają od chorych zakaźnie obowiązek kąpiel, dezynfekcja ubrania, a nawet całkowita zmiana, aby drugim choroby nie przenieść. $^{\mathrm{b}}$

14.) Wróciwszy od chorych nie ma zwyczaju aby potem (choć o to proszą) utrzymywały stosunki, przez nawiedzanie lub przyjmowanie u siebie, stają się nieznane z chwilą wyjścia od chorego. ${ }^{\mathrm{c}}$

15.) Nie wolno przyjmować żadnych upominków, pod żadnym pozorem. Wynagradzanie jakie wnoszą do Zakładu za kwitem, dozorczyni też $/ /$

[s. nlb. 11] 16.) nie zabiera, tylko odsyłają do kancelarii. ${ }^{\mathrm{e}}$

17.) Chodzą bez różnicy wyznań, powinny być niezmiernie ostrożne w ochrzczeniu, czekać w tym ostatecznej chwili, bo potem jak przyjdzie do zdrowia jest kłopotliwe czuwać nad tym. ${ }^{\mathrm{f}}$

18. Niech też Ojciec powie nam czy chrzest dla dorosłych Żydów w ostatnim momencie on ustalony bez ich intencji jest ważny, bo są tu podwójne zdania, i co rzeczywiście w takim razie robić. ${ }^{\mathrm{g}}$

19. Od ceremonii in[n]owierców gdyby były obecne powinny się umieć uchylić.

20.) Przygotować dla każdego wyznania wszystko co potrzeba do ich ceremonii, dotąd robią to ile im wskażą. ${ }^{\text {h } / /}$

[s. nlb. 12]

21.) Doktorów nie narzucać, zostawiając każdemu wybór do kogo kto ma zaufanie.

22.) Lekarstwa i wszelkie zlecenia doktora akuratnie spełniać, a samym niczego nie wprowadzać.

\footnotetext{
${ }^{\mathrm{b}}$ Z lewej strony pionowa kreska wzdtuż tekstu punktu 13.

${ }^{\mathrm{c}} Z$ lewej strony pionowa kreska wzdluż tekstu punktu 14 na dtugości trzech wersów tekstu.

${ }^{\mathrm{d}}$ Z lewej strony pionowa kreska wzdłuż tekstu punktu 15 na dlugości dwóch wersów tekstu.

${ }^{\mathrm{e}}$ Z lewej strony pionowa kreska wzdtuż tekstu punktu 16.

${ }^{\mathrm{f}} Z$ lewej strony pionowa kreska wzdtuż tekstu punktu 17 na dtugości trzech wersów tekstu.

${ }^{\mathrm{g}}$ Punkt 18 z góry, dołu i lewej strony zakreślony atramentem, którym pisany był tekst.

${ }^{\mathrm{h}} \mathrm{Z}$ lewej strony pionowa kreska wzdluż tekstu punktu 20 na dlugości dwóch wersów tekstu.
} 
23.) Do dozorczyni należy porządek w izbie chorego, utrzymanie w czystości wszelkich naczyń, sprzętów używanych przy chorym, dla chorego, o ile potrzeba, sama przyrządza posiłek, powinna się tego w domu uczyć, aby umiała kleik, rosołek, kurczątko, befsztek, $\mathrm{ko}[\mathrm{m}]$ pocik, itp.

Co do zmiany dozorczyń, u nas okazało się prawie niemożebnym ustanowić termin, ile to było próbowane zawsze musieliśmy odstąpić tą nową dyżurną bez narażenia się na straszną awanturę i całkowite wyrzuce[nie]// [s. nlb. 13] nas nie obeszło się, czasem można więcej sztuką niż zasadą kierować się [ss].

Ogólnych zasad nie można nakreślić, bo w każdym domu inna metoda.

Czy się to na co przyda? ${ }^{\mathrm{a}}$

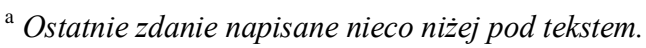




\section{Bibliografia}

\section{Źródla archiwalne}

Archiwum Zgromadzenia Sióstr Franciszkanek od cierpiących (AFC):

- sygn. A II, T. I-Konst/7, Konstytucje pierwotne - Najdawniejsza Ustawa dana przez o. Honorata, oryginał, p. 61-137.

- sygn. A III, T. III-Instr/33, Instrukcje, Zalecenia dla pielęgnowania chorych w zakładach, szpitalach lub w domach prywatnych, s. 85-115.

- sygn. A III, T. IV-Instr/53, 54, Rady dla osób oddających się pielęgnowaniu chorych, cz. 1 i 2.

- sygn. C I, T. I-MK/12, Gruszczyńska K., Informacje o pielęgnowaniu chorych dla Sióstr.

- sygn. C I, T. I-MK/46, Kozielewski I., Życiorys Matki Założycielki.

- sygn. C I, T. II-MK/63, Wspomnienia o Matce Gruszczyńskiej, by z nią obcować wewnętrznie siostry Janiny Pogorzelskiej.

- sygn. C I, T. II-MK/67, H. Władzińska, Wspomnienia.

- sygn. C I, T. II-MK/75, Wspomnienia o śp. Matce Kazimierze Gruszczyńskiej skreślone przez mec. Waleriana Strzałkowskiego Radcę Prawnego Zgromadzenia od 1905 r. do końca [swego] życia, tj. 1953.

- sygn. C I, T. IV-MK/110, Listy do osób świeckich, przyjaciół i dobrodziejów.

- sygn. C II, T. II- MŁ/34, M. Łazowska, Historia domu Sanatorium św. Józefa Warszawa.

- sygn. D I, T. I-San/9, Regulamin Sanatorium Św. Józefa ułożony przez Matkę Kazimierę.

- sygn. E I, T. I-Kr/7, Kronika kaplicy w Kozienicach 1919-1956, In nomine Domini, s. 19-32.

\section{Źródła drukowane}

Gruszczyńska K., Historia Zgromadzenia S.S. Franciszkanek od Cierpiacych, oprac. L. Czermińska, J. Marecki, Kraków 2019.

\section{Publikacje}

Czermińska L., Duchowość Sióstr Franciszkanek od Cierpiąych. Studium na podstawie dokumentów Zgromadzenia, Łódź 2009.

Czermińska L., Wszystko zaczęło się w Kozienicach. Życie i dzieło Stugi Bożej Kazimiery Gruszczyńskiej (1848-1927), Kozienice 2017.

Dębowska K., Zgromadzenie Sióstr Franciszkanek od Cierpiacych w latach 1882-1952, „Prawo Kanoniczne. Kwartalnik Prawno-Historyczny”, t. 15, 1972, nr 1-2, s. 159-229.

Majda A., Zalewska-Puchała J., Stuletnia tradycja ksztatcenia pielegniarek w Krakowie, ,Problemy Pielęgniarstwa”, 2012, nr. 20 (1), s. 92-101. 
Matoga H., Miłosierdzie, które dało początek pielęgniarstwu, „Małopolskie Pielęgniarki i Położne”, 2015, nr 17, s. 2-3.

Mazur E., Szpitale w Królestwie Polskim w XIX wieku, Warszawa 2008.

Podgórska-Klawe Z., Szpitale warszawskie 1388-1945, Warszawa 1975.

Slosorz T., Ksztatcenie zawodowe pielęgniarek w ujęciu historycznym, „Polski

Przegląd Nauk o Zdrowiu", 2014, nr 4 (41), s. 298-304.

Olszewski D., W służbie cierpiacym. Charyzmat Kazimiery Gruszczyńskiej (1848-1927), Niepokalanów 1991.

Stępień J., Rys życia Kazimiery Gruszczyńskiej, [w]: Polskie teksty ascetyczne, red. J. Bar, t. II, Warszawa 1981, s. 227-282.

MAGDALENA MAROSZ

\section{„CZUWAĆ JAK NAJTROSKLIWSZA MATKA NAD DZIECKIEM". DZIAŁANIA MATKI KAZIMIERY GRUSZCZYŃSKIEJ W KIERUNKU PRZYGOTOWANIA SIÓSTR FRANCISZKANEK OD CIERPIĄCYCH DO PRACY PIELĘGNIARSKIEJ}

Streszczenie: W 1882 roku w Warszawie założone zostało, jako jedno ze zgromadzeń ukrytych powstałych z inicjatywy o. Honorata Koźmińskiego, Zgromadzenie Sióstr Franciszkanek od Cierpiących. Zajmować się miało szeroko rozumianą opieką nad cierpiącymi i potrzebującymi. Od początku istnienia Zgromadzeniem kierowała Kazimiera Gruszczyńska, jego założycielka. Zdając sobie sprawę z ogromnych potrzeb w zakresie opieki nad chorymi zarówno w szpitalach i innych zakładach leczniczych, jak i w domach prywatnych posługę tę traktowała, jako jeden z ważniejszych obowiązków sióstr. Przełożona dbała, aby siostry kształciły się w zakresie pielęgniarstwa już od chwili wstąpienia do zakonu. Sama opracowywała dokumenty i instrukcje pomocne $\mathrm{w}$ pracy $\mathrm{z}$ chorymi, kierowała siostry na kursy i szkolenia, niestrudzenie nadzorowała ich pracę z pacjentami. Doprowadziła do wybudowania w Warszawie szpitala, tak zwanego „Sanatorium”, jednego z najnowocześniejszych w tamtym czasie, służącego także, jako miejsce praktycznego szkolenia franciszkanek. W planach Kazimiery Gruszczyńskiej było również założenie szkoły pielęgniarskiej, jednak w związku z wielorakimi trudnościami musiała zrezygnować z tego zamiaru. Warto podkreślić, że działania Matki Przełożonej mające na celu jak najlepsze przygotowanie sióstr do pracy z chorymi były, jak na owe czasy, nowatorskie dla zawodowego kształcenia pielęgniarek. Sama nie mając przygotowania medycznego doskonale rozumiała potrzeby i wymagania w tym zakresie. Równocześnie zabiegała o to, by przygotowanie fachowe było mocno powiązane $\mathrm{z}$ autentyczną religijnością sióstr. Zgromadzenie Sióstr Franciszkanek od Cierpiących odwołujące się do duchowości 
franciszkańskiej, wywodzi z niej podstawowy dla siebie apostolat posługi cierpiącym, prezentowany wielokrotnie w Konstytucjach i innych dokumentach, a także w pismach i działaniach K. Gruszczyńskiej.

Słowa kluczowe: Kazimiera Gruszczyńska, Honorat Koźmiński, Zgromadzenie Sióstr Franciszkanek od Cierpiących, Królestwo Polskie, zgromadzenia ukryte, szpitale, pielęgniarstwo, szkoła pielęgniarska.

\title{
„LIKE A MOST CARING MOTHER TENDING HER CHILD”. THE ACTIVITIES OF MOTHER KAZIMIERA GRUSZCZYŃSKA TO PREPEARE THE FRANCISCAN SISTERS OF SUFFERING FOR NURSING WORK
}

\begin{abstract}
In 1882, the Congregation of the Franciscan Sisters of Suffering was founded in Warsaw as one of the hidden life congregations formed on the initiative of Fr. Honorat Koźmiński. The aim of the congregation was to take care of the suffering and the needy. From the beginning of its existence, the Congregation was managed by Kazimiera Gruszczyńska, its founder. Realizing the great needs in the care of the sick, both in hospitals and other establishments, as well as in private homes, she treated this service as one of the most important duties of the sisters. The superior took care that the sisters were educated in nursing from the moment they joined the convent. She herself developed documents and instructions to help the work with the sick, directed the sisters to courses and trainings, and supervised their work with patients. She led to the construction of a hospital in Warsaw, the so-called "Sanatorium", one of the most modern at that time, also serving as a place for practical training for Franciscan Sisters. In Kazimiera Gruszczyńska's plans there was also the establishment of a nursing school, but due to multiple difficulties, she had to give up this intention. It is worth noting that the Mother Superior's actions aimed at preparing the sisters for the best possible work with the sick were, for those times, innovative for the vocational training of nurses. Not having medical training herself, she understood the needs and requirements in this area perfectly well. At the same time, she took care that the professional preparation should be strongly linked to the authentic religiousness of the sisters. The Congregation of the Franciscan Sisters of Suffering, based on Franciscan spirituality, derives from it the basic apostolate of serving the suffering, presented many times in the Constitutions and other documents, as well as in the writings and activities of K. Gruszczyńska.
\end{abstract}

Keywords: Kazimiera Gruszczyńska, Honorat Koźmiński, Congregation of the Franciscan Sisters of Suffering, the Kingdom of Poland, hidden-life congregations, hospitals, nursing, nursing school. 
132

MAGDALENA MAROSZ 